\title{
Pengaruh Penggunaan Musik Daerah Untuk Meningkatkan Kompetensi Kecepatan Dan Ketepatan Mengetik Mahasiswa
}

\author{
Oleh: \\ Maya Setiawardanidan Tintin Suhaeni \\ Jurusan Administrasi Niaga, Politeknik Negeri Bandung, Bandung 40012
}

\begin{abstract}
Mastery of keyboarding being part urgent to communicate through the computer,and very important,especially students who study in the field of business. On the other side, individual performance also influenced by the work environment, and music is one form the environment that could effect keyboarding performance. A model that can describe this is stimulus-responsible model of mehrabian-russell which explains that music can affect the performance of individual writing. Almost all of Indonesia has a typical traditional music. Therefore, research is needed to identify the effects of traditional music to enrich the area of innovation in strategies and techniques of learning keyboarding skills. In this study conducted experiment on two groups, the treatment groups(traditional music) and control group (without traditional) and questionnaire to strengthen the experimental results. In preliminary tests of typing, both groups had a mean AWPM identical or similar. Furthermore, tests carried one, where the threatment group listened to five kinds of music Java, Sunda, and Bali. The test result and the result of the questionnaire showed that (typing skills shown by the average value of AWPM) will increase significantly used of traditional music as the background. So, the genre of the traditional music can be stimulant to improve average performance of AWPM. There are three traditional musics that can improve student typing speed and accuracy significantly, a regional music cublek-cublek Suweng, Kebiar Bali, and Oleg Tambuliningan, but Cublek-cublek Suweng is a genre of traditional music that has the best effect. Therefore, process of learning courses keyboarding skills need to use instrumental traditional music, especially instrumental music that has a fast tempo and cheerfuly.
\end{abstract}

Keywords: keyboarding skill, folk music, AWPM (Adjusted Words Per Minute)

\section{PENDAHULUAN}

Mata kuliah keyboarding skill diberikan kepada seluruh mahasiswa di Jurusan Administrasi Niaga yang jumlahnya sekitar 800-an, bahkan beberapa program studi di luar jurusan Administrasi Niaga, seperti program studi Keuangan Perbankan, Akuntansi, Keuangan Syariah, Akuntansi Manajemen Pemerintah mendapatkan mata kuliah ini. Melihat permintaan yang begitu banyak, penulis mengasumsikan bahwa kompetensi ini sangat penting bagi mahasiswa untuk menghadapi dunia kerja yang semakin kompetitif. Di samping itu, untuk dapat memasuki persaingan global, maka keterampilan mengetik mahasiswa harus diselaraskan dengan tuntutan global di mana kecepatan minimal untuk pengetik profesional adalah $50 \mathrm{kata} /$ menit (Wikipedia). Pendapat ini juga sesuai dengan yang dikemukakan oleh Michael Page International Inc., specialists in office support recruitment bahwa seorang sekretaris atau administrator harus memiliki kecepatan mengetik minimal $50 \mathrm{kata} / \mathrm{menit}$.

Mata kuliah keyboarding skill yang diajarkan kepada mahasiswa menekankan pada kemampuan mengetik sepuluh jari dengan sistem buta, artinya mahasiswa ketika mengetik, mereka tidak melihat papan ketik, tapi pandangan atau mata mereka mengarah kepada naskah yang akan diketik. Dengan demikian mereka akan menghasilkan kecepatan dan ketepatan mengetik di atas rata-rata dibanding dengan kemampuan mereka yang tidak mempunyai kemampuan keyboarding. Seperti yang dijelaskan oleh Wentling (1992) yang menyatakan bahwa keyboarding skills adalah: 
"The act of placing information into a computer through the use of typewriter - like keyboard, involving the placement of fingers on designated keys on the middle "home" row of the keyboard and moving fingers as needed to depress other keys without looking at the keyboard".

Selain itu, individu yang menguasai keyboarding skills akan mendapatkan manfaat berupa: peningkatkan penggunaan waktu dan efektivitas pemanfaatan komputer (National Business Education Association, 1992). Nieman (1996) menyatakan bahwa penguasaan keyboarding skills memiliki konsekuensi sebagai berikut: mampu membuat komposisi lebih cepat (surat, laporan, artikel, dll.), merasa bangga dengan pekerjaannya, memproduksi dokumen dengan penampilan yang lebih rapi, memiliki motivasi yang lebih baik, serta mendemonstrasikan peningkatan dalam "language arts skills".

Penguasaan tuts-tuts pada papan ketik, dalam istilah pengetikan disebut dengan kemampuan keybording (keyboarding skill). Teknik yang digunakan adalah teknik mengetik sepuluh jari dan sistem buta. Teknik ini masing-masing jari mempunyai fungsi kerja tersendiri, mulai dari kelingking sampai ibu jari mempunyai rumah pada tuts-tus tertentu yang dinamakan dengan home keys, sehingga beban terdistribusi untuk semua jari, baik pada tangankiri maupun tangan kanan. Lalu yang dimaksud dengan sistem buta adalah mata mahasiswa tidak boleh melihat tuts pada papan keyboard, tetapi pandangannya diarahkan pada naskah (manuskrip). Dari tahun ke tahun mahasiswa diberi metode yang sama untuk meningkatkan kemampuan keyboarding skill. Mengapa demikian? Karena teknik mengetik sepuluh jari dengan sistem buta, merupakan teknik yang sudah paripurna. Teknik ini bersifat umum, sedangkan untuk menerapkan sistem buta, mahasiswa sejak awal latihan tidak diperbolehkan untuk melihat tuts-tuts dalam keyboard, bahkan mulai pertemuan ke tiga dan seterusnya papan ketik ditutup dengan lakban hitam, sehingga hurufhuruf pada papan ketik tidak terlihat. Melihat demikian penting kompetensi keyboarding dengan bantuan alat komputer, maka Jurusan Administrasi Niaga mempersiapkan hal tersebut dengan membangun laboratorium yang memiliki multi fungsi, yaitu: laboratorium yang biasa digunakan untuk praktik pengarsipan berbasis elektronik (electronic filing system), juga difungsikan untuk mempelajari keyboarding skills.

Pembelajaran keyboarding skillyang diselenggarakan di laboratorium EFS dan Keyboarding Skills menggunakansoftware keyboarding skills, yaitu software Mavis Beacon 20. Mavis Beacon sebagai salah satu vendor software pengetikan meyakinkan para user jika mereka berlatih selama lima belas menit dalam waktu dua minggu dapat meningkatkan kompetensi keyboarding skill, minimal 25\% (Learning Company Properties, Inc., 1999: 93).

Mengapa menggunakan software Mavis? Salah satu keuntungan bahkan keunggulan dari software ini adalah mahasiswa bisa belajar mandiri, karena sudah dirancang untuk sistem pembelajaran individual, jadi kemajuan masing-masing mahasiswa tidak selamanya bersama-sama, namun tergantung dari kecepatan mereka dalam menyelesaikan tahapan kurikulum yang ada pada software tersebut. Dengan demikian paradigma pembelajaran dari asalnya berpusat pada guru (teacher oriented) menjadi berorientasi pada siswa (student oriented). Hal ini diperkuat dengan penelitian Raharso dan Nurswastuti (2004: 165) yang menjelaskan bahwa pembelajaran keyboarding skill berbasis komputer bisa memfasilitasi paradigma student oriented. Tegasnya dengan menggunakan software keyboarding skill, mahasiswa bisa belajar secara mandiri, kapan saja dan dimana saja. Akan tetapi, walaupun software memainkan peran penting dalam meningkatkan keyboarding skills, MacLean (1994) menyatakan bahwa software tidak dapat menggantikan peran dosen yang memiliki kualifikasi tinggi dalam pembelajaran keyboarding skill. Hasil penelitian Wiseman (2000) menyatakan bahwa software pengetikan tersebut hanya menolong pada individu yang memiliki motivasi dan bisa mengevaluasi kinerja mereka sendiri.

Jadi, keterlibatan aktif seorang dosen dalam hal ini masih tetap diperlukan dan memiliki peran penting dalam menentukan sukses tidaknya mahasiswa dalam mengadopsi keyboarding skill. Wiseman (2000) menyatakan bahwa dosen yang mengimplementasikan pelatihan keyboarding skill secara efektif akan menghasilkan mahasiswa yang memiliki "a lifelong advantage". Cooper (1983), menjelaskan bahwakeyboardingskills adalah "a life long skill"

Berdasarkan pengalaman kami saat di laboratorium, jika mahasiswa tidak diawasi dengan seksama, mereka cenderung lebih memilih games dibanding dengan content, seyogyanya untuk mendapatkan bonus games, mahasiswa harus bertahap melakukan pembelajaran sesuai dengan kurikulum yang ada dalam Mavis Beacon. Hal ini dapat dikonfirmasikan dengan hasil penelitian Alaska Departement of Education (1991) juga mengidentifikasi bahwa adopsi software keyboarding skill tanpa pengawasan dosen/instruktur membuat mahasiswa lebih sering menggunakan games yang ada di dalam 
software tersebut. Games memang sangat disukai oleh user, akan tetapi mahasiswa umumnya hanya fokus pada kecepatan mengetik daripada teknik mengetik, sehingga mereka cenderung menggunakan teknik pengetikan "hunt and peck" atau sistem sebelas jari. Hal tersebut terjadi karena mahasiswa lebih termotivasi untuk memenangkan games daripada mempelajari teknik mengetik sepuluh jari dan sistem buta. Oleh karena itu Alaska Departement of Education (1991) merekomendasikan bahwa "games should be restricted to drills and enrichment activities".

Faktor-faktor yang berpengaruh terhadap kemampuan individu dalam mengadopsi keyboarding skill, selain faktor dosen adalah faktor lingkungan fisik. Penciptaan lingkungan fisik yang yang aman dan nyaman akan membuat mahasiswa belajar nyaman pula. Hal ini diperkuat oleh hasil penelitian Raharso \& Raharso (2006) yang menyatakan bahwa lingkungan fisik yang ada di sekitar individu membuat dia menjadi merasa nyaman atau sebaliknya.Rasa nyaman dan tidak nyaman tersebut akan mempengaruhi semangat belajar, terutama untuk mahasiswa yang mempelajari keyboarding skill, Kondisi tersebut bisa dijelaskan oleh Model Stimulus-Response dari Mehrabian-Russel (Richardson et al., 1996).

Salah satu bentuk lingkungan fisik tersebut adalah musik. Musik adalah stimulus yang diperoleh oleh individu yang sedang belajar keyboarding skill. Setelah mendapat stimulus tersebut, individu akan terpengaruh mood atau emosinya. Pengaruh tersebut selanjutnya akan muncul dalam bentuk respon berupa penerimaan (approach) atau penolakan (avoidance) terhadap stimulus musik tersebut. Ketika individu menolak stimulus tersebut, berarti dia tidak menyukai stimulus tersebut, dan sebaliknya. Hal ini dapat dikonfirmasi melalui penelitian Suryani \& Raharso (2005) yang menyatakan kenyamanan atau ketidaknyamanan tersebut akan mempengaruhi semangat kerja individu dalam mempelajari teknikteknik keyboarding skill. Kajian dalam ilmu manajemen kantor juga menyatakan hal yang sama, yaitu: musik bisa mempengaruhi kinerja seorang individu (Suryani \& Raharso, 2005).

Hal tersebut diperkuat oleh penelitian Soejoeti \& Kurnianto (2005) yang menjelaskan bahwa ada pengaruh yang positif dan signifikan musik pengiring kerja terhadap motivasi kerja, kepuasan kerja dan produktivitas kerja karyawan.

Hasil penelitian lainnya, yaitu Jensen (1931) yang meneliti pengaruh dari genre musik jazz (misal: "Valencia" oleh Mayflower Serenaders dan "At the Prom" dari Irving Mills and his Modernists) serta dirge (misal: "Death of Ase" oleh Victor Concert Orchestra dan "Indian Lament" oleh Fritz Kreisler dan Vincent O’Brien) terhadap kecepatan dan ketepatan pengetikan. Colona (2008) juga yang berhasil mengidentifikasi bahwa musik bergenre "fast rock" memiliki pengaruh yang lebih dominan terhadap kecepatan pengetikan seorang individu dibandingkan musik bergenre "fast rap".

Dalam proses pembelajaran keyboarding skill musik sebagai salah satu lingkungan fisik perlu diberdayakan untuk memotivasi dan mempertinggi konsentrasi belajar mahasiswa, sehingga akan berpengaruh terhadap pencapaian kompetensi keyboarding. Alasan mengapa musik sangat penting untuk lingkungan belajar adalah karena musik sebenarmya berhubungan dan mempengaruhi kondisi fisiologis manusia (De porter \& Hernacki,2000)

Berdasarkan hasil penelitian Tjahjawati \& Raharso (2013) bahwa musik memang bisa memberi pengaruh yang signifikan kepada kinerja pengetikan. Kehadiran musik bisa menaikkan kecepatan mengetik secara signifikan. Dari hasil penelitian itu juga direkomendasikan untuk meneliti lebih lanjut tentang musik daerah. Oleh sebab itu, penelitian ini ingin mengetahui pengaruh musik daerah terhadap kecepatan dan ketepatan mengetik.

Satu tahun ke belakang, sistem pembelajaran di Laboratorium Electronic Filing System (EFS) dan Keyboarding Skillsudah memberdayakan musik (pop, jazz,blues dan rock) sebagai pengiring mempelajari keyboarding skill. Hasilnya sudah ada kemajuan namun belum optimal, hal ini sesuai dengan hasil penelitian Tjahjawati \& Raharso (2013). Namun saat ini belum diberdayakan musik daerah sebagai stimuli lingkungan fisik yang bisa mempengaruhi proses pengadopsian keyboarding skill.

Hampir di seluruh wilayah Indonesia mempunyai seni musik tradisional yang khas dan keunikan tersebut bisa dilihat dari teknik permainannya, penyajiannya maupun bentuk/organologi instrumen musiknya. Hampir seluruh seni tradisional Indonesia mempunyai semangat kolektivitas yang tinggi sehingga dapat dikenali karakter khas orang/masyarakat Indonesia. Dengan demikian, mahasiswa sebagai masyarakat yang berasal dari daerah tertentu akan sangat hafal dan menjiwai musik dari daerahnya masing-masing, sehingga mereka dapat menikmati dan menimbulkan perasaan positif pada dirinya. 
Oleh karena itu, untuk meningkatkan proses pembelajaran keyboarding skill dengan komputer dan software keyboarding skill masih dapat ditingkatkan lagi dengan pengadopsian variabel musik daerah. Musik yang dapat meningkatkan emosi positif individu (McCraty et al., 1996; Suryani \&Raharso, 2005) merupakan stimuli yang dapat diujicobakan untuk menghasilkan respon yang positif terhadap peningkatan kemampuan keyboarding skill mahasiswa.

\section{Perumusan Masalah}

Berdasarkan latar belakang masalah, maka masalah penelitian ini adalah:

a. Apakah musik daerah memberi pengaruh terhadap peningkatan kecepatan dan ketepatan mengetik mahasiswa?

b. Genre musik daerah mana yang dapat memberi pengaruh terhadap kecepatan dan ketepatan mengetik mahasiswa?

\section{Tujuan dan Manfaat Penelitian}

Selaras dengan perumusan masalah, penelitian ini bertujuan untuk:

a. Mengetahui apakah musik daerah dapat memberikan pengaruh terhadap peningkatan kecepatan dan ketepatan mengetik mahasiswa.

b. Mengetahui genre musik daerah mana yang dapat memberikan pengaruh terhadap peningkatan kecepatan dan ketepatan mengetik mahasiswa.

Sedangkan manfaat yang dari hasil penelitian ini adalah sebagai berikut:

a. Dapat mendesain percoban baru tentang jenis-jenis genre musik dan tempo musik yang bisa menjadi stimuli yang diterima oleh mahasiswa sehingga keyboarding skill mereka meningkat secara signifikan.

b. Dapat mendesain ulang lingkungan fisik (mengakomodasi musik) Laboratorium EFS dan Keyboarding Skill, sehingga proses pembelajaran menjadi lebih efektif dan efisien.

\section{TINJAUAN PUSTAKA}

\section{Kompetensi Mengetik}

Mengetik adalah kegiatan kantor yang paling sering dilakukan karena dokumen-dokumen kantor seperti surat, memo, laporan-laporan dibuat dengan cara diketik. Dalam dunia bisnis, kita dituntut untuk melakukan pekerjaan dengan cepat dan tepat. Untuk itu, agar dapat mengetik cepat dan tepat, maka diperlukan penguasaan keyboard.

Pada tahun 1873 Remington pertama kali memasarkan mesin tik secara komersial, maka sejak saat itu riset tentang pengajaran bagaimana menguasai keyboard mulai bermunculan. Salah satu hasil riset tersebut adalah sistem pengetikan sepuluh jari dan sistem buta (Robinson et al., 1993). Permintaan pengetikan dengan cepat dan tepat semakin banyak terutama setelah Perang Dunia II (Bartholome, 2002).

Akibat dari keadaan tersebut di atas, maka pembelajaran yang ditujukan untuk menguasai keyboard juga mulai diperkenalkan di sekolah dan perguruan tinggi. Selanjutnya, ketika keyboard semakin mendominasi, terutama sebagai alat utama peng-input data di komputer, maka kursus atau mata kuliah keyboarding skill yang tadinya bersifat pilihan telah berubah menjadi mata kuliah wajib, terutama di sekolah bisnis (Skifstad, 2003).

Keyboarding skill adalah keterampilan mengetik dengan menguasai seluruh tuts yang ada pada keyboard mesin tik atau komputer. Oleh sebab itu, tujuan dari mata kuliah keyboarding skill di Jurusan Administrasi Niaga adalah agar mahasiswa mampu mengetik dengan sistem buta sepuluh jari, sehingga pada akhir semester mereka mampu mengetik dengan kecepatan miminal $40 \mathrm{kata} / \mathrm{menit}$ dan tingkat ketepatan minimal98\% untuk pengetikan yang menggunakan komputer. Hal tersebut berlaku untuk mahasiswa yang baru pertama kali mempelajari keyboarding skill. Penetapan tujuan mata kuliah tersebut didasarkan dari hasil penelitan Setiawardani dkk ( 2013) bahwa kecepatan mengetik yang dibutuhkan oleh industri adalah $40 \mathrm{kata} / \mathrm{menit}$. Dan didasarkan pendapat Wetzel (1985) yang menyatakan bahwa mahasiswa akan tetap memiliki keterampilan mengetik ketika mereka telah melalui kecepatan mengetik lebih dari $20 \mathrm{kata} /$ menit. Artinya, apabila kecepatan tersebut sudah terlewati, maka para ahli mengindikasikan mahasiswa tersebut biasanya akan bisa memelihara kemampuan keyboarding mereka. Namun demikian, untuk menghadapi persaingan global, maka mahasiswa dituntut untuk meningkatkan 
lagi kecepatan dan ketepatan mengetiknya sesuai dengan standar untuk pengetik profesional yaitu minimal $50 \mathrm{kata} /$ menit (Wikipedia).

Dalam pengajaran keyboarding skill tersebut, mahasiswa diajarkan bagaimana memfungsikan sepuluh jari tangan dalam mengetik tuts yang ada pada keyboard. Setiap jari tangan memiliki fungsi dan tanggung jawabnya masing-masing, sehingga kegiatan pengetikan dapat dilakukan dengan cepat dan tepat. Kecepatan dan ketepatan mengetik mahasiswa akan ditest secara berkala untuk mengetahui tingkat penguasaan keyboard nya. Mahasiswa dapat menghitung sendiri kecepatan dan ketepatan mengetiknya. Walaupun, hal tersebut sebenarnya akan dihitung secara otomatis oleh softwarekeyboarding skill (misal: Typing Tutor, Mavis Beacon), pengetahuan tersebut berguna agar mahasiswa memahami makna dari kecepatan dan ketepatan. Secara manual, cara penghitungan kecepatan dan ketepatan mengetik adalah sebagai berikut.

a. Menghitung kecepatan; pertama, menghitung jumlah kata yang berhasil diketik dengan cara membagi jumlah hentakan yang berhasil diketik dibagi dengan lima (1 kata $=5$ hentakan). Selanjutnya, jumlah kata yang berhasil diketik dibagi waktu yang dipergunakan untuk mengetik tersebut.

Berikut rumus menghitung kecepatan.

Jumlah kata terketik = jumlah hentakan/5

Jumlah kata/menit = jumlah kata/waktu

b. Menghitung ketepatan; pertama, menghitung jumlah kesalahan mengetik, dimana kesalahan tersebut dihitung satu/kata (Philips \& Radford, 1984). Maksudnya, apabila dalam satu kata terdapat lebih dari satu, maka tetap dihitung satu kesalahan. Selanjutnya, menghitung ketepatan yaitu jumlah kata yang berhasil diketik dikurangi jumlah kesalahan dibagi jumlah kata kata yang berhasil diketik dikalikan dengan $100 \%$.

Rumus menghitung ketepatan.

\begin{tabular}{|c|}
\hline Jumlah kata terketik - jumlah kesalahan \\
\hline Jumlah kata terketik \\
x $100 \%$ \\
\hline
\end{tabular}

Pada saat ini, keyboarding skill bukan untuk kebutuhan vokasional saja, tetapi menjadi kebutuhan untuk dapat berkomunikasi, mengekstrak dan menyebarkan informasi. Kemampuan keyboarding yang kurang akan menyebabkan seseorang menjadi kurang memiliki pengetahuan, karena pada saat ini hampir semua orang menggunakan komputer dan internet untuk memperoleh atau menyebarkan informasi (Schmidt, 1985). Di abad teknologi informasi semua orang membutuhkan komputer agar mereka bisa survive (Adomi \& Anie, 2006: 10; Wiseman, 2000). Walaupun saat ini banyak alat yang bisa digunakan sebagai alat meng-input komputer, tetapi keyboard tetap memainkan peran sentral (Business Education Center. 2005: 2). Artinya, menguasai keyboard tetap menjadi keterampilan yang penting.

Disamping itu, hasil penelitian yang dilakukan Nieman (1996), bahwa mereka yang memiliki kemampuan keyboarding skill memperlihatkan kemampuan mengarang yang lebih baik, bangga pada apa yang dia kerjakan, memproduksi dokumen dengan penampilan yang rapi, memiliki motivasi yang lebih tinggi, dan mendemonstrasikan ketrampilan berbahasa yang lebih baik. Siswa yang mempelajari keyboarding skill juga memperlihatkan antusiasme yang tinggi ketika menggunakan komputer untuk mengerjakan paper work mereka (Business Education Center. 2005: 56). Hal ini didukung oleh Bartholome (1996) yang menyatakan bahwa siswa yang memahami bagaimana menggunakan keyboard secara efektif dan efisien akan sukses di masa depan (Business Education Center. 2005: 56).

\section{Penggunaan Musik Daerah dalam Mengetik}

Musik di kantor membantu meningkatkan kepuasan dan produktivitas kerja. Musik juga menyembuhkan kelelahan mental dan fisik, serta mengurangi ketegangan syaraf.Musik juga dapat menenangkan otak, dan jikalau otak tenang maka proses berfikir akan lebih terarah dan terkendali, kita akan lebih mudah menyelesaikan persoalan yang kita hadapi. Otak yang rileks dan tenang otomatis akan 
lebih mudah menerima, mencerna dan mengolah informasi, emosi juga akan lebih stabil. Hal ini didukung para praktisi dan akademisi yang meyakini bahwa musik memiliki pengaruh terhadap mood, emosi, dan perilaku individu (Hallam et al., 2002). Musik merupakan "environmental stimuli" yang diterima oleh individu dan selanjutnya akan mempengaruhi "emotional states" dari individu tersebut. Hasilnya, individu tersebut akan mengeluarkan dalam bentuk approach atau avoidance. Respon dalam bentuk approach mengindikasikan individu tersebut menerima stimuli musik dan merasa senang. Hal ini menyebabkan individu tersebut akan mengetik dengan penuh semangat. Sebaliknya, respon avoidance mengindikasikan individu tersebut tidak merasa senang dengan stimuli musik yang menimpa dirinya, akibatnya, individu merasa tidak memiliki semangat untuk mengetik. Model seperti ini adalah model yang dikembangkan oleh Mehrabian dan Russel, dan diberi nama sebagai model Stimulus-Response (Richardson et al., 1996).

Berdasarkan perspektif psikologi lingkungan tersebut, kemudian musik diaplikasikan dalam pembelajaran maupun implementasi dari keyboarding skills. Misalnya, Jensen (1931) meneliti pengaruh dari genre musik jazz serta dirge terhadap kecepatan dan ketepatan mengetik. Sedangkan Colona (2008) mengidentifikasi bahwa musik bergenre "fast rock" memiliki pengaruh yang lebih dominan terhadap kecepatan pengetikan seorang individu dibandingkan musik bergenre "fast rap". Dalam kajian ilmu manajemen kantor juga menyatakan hal yang sama, yaitu: musik bisa mempengaruhi kinerja seorang individu (Suryani \& Raharso, 2005). Hal ini juga diperkuat oleh penelitian Soejoeti \& Kurnianto (2005) yang menjelaskan bahwa ada pengaruh yang positif dan signifikan musik pengiring kerja terhadap motivasi kerja, kepuasan kerja dan produktivitas kerja karyawan.

Musik daerah atau musik tradisional adalah musik yang hidup di masyarakat secara turun temurun, yang biasanya digunakan untuk upacara adat atau untuk memperingati hari-hari besar di daerahnya. NKRI adalah sebuah negara yang meliputi ribuan pulau yang terbentang dari Sabang sampai Merauke, dimana dari sekian banyaknya kepulauan beserta masyarakatnya tersebut lahir, tumbuh dan berkembang berbagai budaya daerah. Seni tradisional yang merupakan jati diri, identitas dan media ekspresi dari masyarakat pendukungnya.Hampir seluruh wilayah NKRI mempunyai seni musik tradisional yang khusus dan khas. Dari keunikan tersebut bisa nampak terlihat dari teknik permainannya, penyajiannya maupun bentuk/organologi instrumen musiknya. Seni tradisonal itu sendiri mempunyai semangat kolektivitas yang tinggi, sehingga dapat dikenali karakter dan ciri khas masyarakat Indonesia, yaitu yang terkenal ramah dan santun.

Untuk lebih mengenal lebih dekat musik tradisional kita dapat dikategorikan menjadi beberapa kelompok yaitu:

1. Instrumen Musik Perkusi. Perkusi adalah sebutan bagi semua instrumen musik yang teknik permainannya dipukul, baik menggunakan tangan maupun stik. Dalam hal ini beberapa instrumen musik yang tergolong dalam alat musik perkusi adalah Gamelan, Kendang, Kecapi, Arumba, Talempong, Sampek dan Kolintang, Rebana, Bedung, Jimbe dan lain sebagainya.

2. Instrumen Musik Gesek. Instrumen musik tradisional yang menggunakan teknik permainan digesek adalah Rebab. Rebab berasal dari daerah Jawa Barat, Jawa Tengah, Jakarta (kesenian betawi). Rebab terbuat dari bahan kayu dan resonatornya ditutup dengan kulit tipis, mempunyai dua buah senar/dawai dan mempunyai tangga nada pentatonis. Instrumen musik tradisional lainnya yang mempunyai bentuk seperti rebab adalah Ohyan yang resonatornya terbuat dari tempurung kelapa. Rebab jenis ini dapat dijumpai di Bali, Jawa dan Kalimantan Selatan.

3. Instrumen Musik Tiup. Suling adalah instrumen musik tiup yang terbuat dari bambu hampir semua daerah di Indonesia dapat dijumpai alat musik ini. Saluang adalah alat musik tiup dari Sumatera Barat, serunai dapat dijumpai di Sumatera Utara, Kalimantan. Suling Lembang berasal dari daerah Toraja yang mempunyai panjang antara $40-100 \mathrm{~cm}$ dengan garis tengah 2 $\mathrm{cm}$.Tarompet, serompet, selompret adalah jenis alat musik tiup yang mempunyai $4-6$ lubang nada dan bagian untuk meniupnya berbentuk corong. Seni musik tradisional yang menggunakan alat musik seperti ini adalah kesenian rakyat Tapanuli, Jawa Barat, Jawa Timur, Madura dan Papua. 
Mahasiswa Politeknik Negeri Bandung berasal dari berbagai daerah dan suku di Indonesia. Dengan demikian, mahasiswa sebagai masyarakat yang berasal dari daerah tertentu akan sangat hafal dan menjiwai musik dari daerahnya masing-masing, sehingga mereka dapat menikmati dan menimbulkan perasaan positif pada dirinya.

\section{Pengaruh Penggunaan Musik Daerah terhadap Peningkatan Kompetensi Mengetik}

Adapun hubungan musik daerah dengan peningkatan kecepatan dan ketepatan mengetik seperti dikemukakan oleh Mehrabian dan Russel (Richardson et al., 1996) bahwa musik merupakan "environmental stimuli" yang diterima individu dan selanjutnya akan mempengaruhi "emotional states" dari individu tersebut. Respon individu terhadap stimuli tersebut dapat berbentuk approach yang mengindikasikan individu tersebut menerima stimuli musik dan merasa senang. Hal ini menyebabkan individu tersebut akan mengetik dengan penuh semangat. Sebaliknya, respon avoidance mengindikasikan individu tersebut tidak merasa senang dengan stimuli musik yang menimpa dirinya, akibatnya, individu merasa tidak memiliki semangat untuk mengetik. Penelitian lain (dalam Salim 2010) menyatakan bahwa musik yang paling berpengaruh terhadap manusia adalah musik yang berasal dari akar budaya dimana manusia itu dibesarkan. Hal ini ditunjang dari hasi penelitian Salim (2010) yang mengungkapkan bahwa musik degung Sunda memiliki pengaruh yang baik dibandingkan musik heavy metal terhadap hasil belajar siswa.

Berdasarkan penjelasan tentang hubungan musik daerah dan kecepatan dan ketepatan mengetik, maka hipotesis penelitian ini adalah:

"Musik daerah memiliki pengaruh secara signifikan terhadap peningkatan kecepatan dan ketepatan mengetik mahasiswa."

\section{METODE PENELITIAN}

Penelitian ini menggunakan metode eksperimen yaitu penelitian yang mencoba meneliti ada tidaknya hubungan sebab akibat dengan cara membandingkan satu atau lebih kelompok eksperimen yang diberi perlakuan dengan satu atau lebih kelompok pembanding yang tidak menerima perlakuan. Populasi dalam penelitian ini adalah seluruh mahasiswa program studi D4 Administrasi Bisnis (1 kelas) dan D3 Administrasi Bisnis (2 kelas) yang telah mendapatkan mata kuliah Keyboarding Skill/Pengetikan Bisnis 1, dan sedang mengikuti mata kuliah Pengetikan Bisnis/Pengetikan Bisnis 2 berjumlah 95 orang, dan teknik sampling yang digunakan adalah teknik probablitiy sampling secara purposif, yang artinya penelitian ini hanya dikhususkan untuk obyek penelitian pada mahasiswa program studi D4 Administrasi dan mahasiswa program studi D3 Administrasi Bisnis yang satu kelas program studi D4 sejumlah 31 orang mahasiswa dan satu kelas program studi D3 sejumlah 32 orang mahasiswa. Jadi total sampel berjumlah 63 orang.

Ada dua alat untuk mengumpulkan data, yaitu data yang diperoleh dari eksperimen berupa hasil test kecepatan dan ketepatan mengetik mahasiswa. Selain itu, untuk memperkuat hasil penelitian, di akhir eksperimen peneliti mendistribusikan angket untuk meyakinkan bahwa faktor musik memang bisa memberi stimulan yang bersifat "favorable" terhadap mahasiswa sehingga kinerja pengetikan mereka menjadi semakin optimal.

Analisis data dalam penelitian ini menggunakan statistik deskriptif. Di samping itu, uji homogenitas/Levene, uji t, post-hoc test (uji lanjut) dengan menggunakan analisis Tukey dan Bonferroni.

\section{HASIL DAN PEMBAHASAN \\ Hasil Identitas Responden}

Sebagian besar responden dari kelompok musik (perlakuan) berasal dari suku Sunda, yaitu sebesar 75\%. Sedangkan suku lainnya, yaitu suku Jawa sebanyak 12.5\%, suku Betawi sebanyak 6.3\%, dan suku Batak sebanyak 3.1\%. Begitu juga, responden kelompok kendali sebagian besar berasal dari suku Sunda yaitu sebanyak $87.1 \%$. Sedangkan suku lainnya, yaitu suku Jawa sebanyak $9.7 \%$ dan suku Batak sebanyak 3.2\%.

Jadi, dari seluruh responden yang ada, sebagain besar berasal dari suku Sunda, sedangkan suku lainnya hanya sebagian kecil saja. Hal ini wajar karena letak geografis kampus Politeknik Negeri Bandung sebagai objek penelitian ini berada di daerah Pasundan yang dihuni oleh suku Sunda. Ini juga 
menggambarkan bahwa mayoritas mahasiswa Program Studi Administasi Bisnis D3 dan D4 berasal dari daerah Bandung dan sekitarnya.

\section{Pengaruh Musik Daerah terhadap Peningkatan Kecepatan dan Ketepatan Mengetik Kecepatan dan Ketepatan (AWPM) Pengetikan Awal}

Dalam rangka mengetahui kecepatan dan ketepatan mengetik responden (AWPM) baik kelompok musik (perlakuan) maupun kelompok kendali pada awal pembelajaran, maka dilakukan test kecepatan dan ketepatan dengan tanpa menggunakan musik daerah. Hasil antara kelompok yang akan mendapat perlakuan (mengetik dengan menggunakan musik tertentu) dengan kelas kendali memiliki nilai rata-rata yang berbeda. Kelompok yang mendapat perlakuan memiliki rata-rata AWPM sebesar 44,750 dengan deviasi standar lebih kecil dari $20 \%(16,95 \%)$. Sedangkan kelompok kontrol memiliki rata-rata AWP sebesar 40,548 dengan deviasi standar lebih besar dari 20\% (22,83\%). Dilihat dari rata-rata AWPM, kelompok perlakuan memiliki nilai yang lebih tinggi sebesar 4,202. Dilihat dari deviasi standar, kelompok perlakuan memiliki deviasi standar yang masih dapat ditoleransi, sedangkan deviasi standar untuk kelompok kendali cenderung memiliki sebaran nilai yang cenderung heterogen (Santoso, 2000).

Akan tetapi, untuk mendapatkan kesimpulan yang lebih kuat digunakan uji beda untuk melihat apakah nilai rata-rata AWPM yang berbeda tersebut memang berbeda secara signifikan. Pertama, analisis dilakukan dengan menggunakan uji Levene, untuk mengetahui apakah varians kedua kelompok tersebut sama atau berbeda.Hasilnya, nilai $F$ hitung adalah 0,542 dengan nilai probabilitas/Sig. 0,464 atau lebih besar dari 0,05 maka disimpulkan bahwa kedua kelompok yang diuji memiliki varians yang sama atau identik. Kedua, analisis dilakukan dengan menggunakan uji t, untuk mengetahui apakah rata-rata kedua kelompok tersebut sama atau berbeda. Hasilnya, output nilai probabilitas $(0,053)$ lebih besar dari 0,05 maka dapat disimpulkan bahwa: rata-rata AWPM kedua kelompok adalah identik atau sama.

Dengan demikian, dapat dibuat kesimpulan bahwa kelompok yang akan mendapat perlakuan maupun kelompok kendali memiliki kemampuan mengetik yang setara, bila dilihat dari kinerja AWPM-nya.

Untuk memastikan bahwa kedua kelompok memiliki kinerja AWPM yang sama atau identik, peneliti melakukan uji tahap kedua (diberi kode Awal2). Berikut ini adalah hasilnya.

Pada tes tahap kedua, kelompok yang akan mendapat perlakuan memiliki nilai rata-rata AWPM lebih tinggi $(45,750)$ dibanding kelompok kendali $(43,258)$. Selain itu, dilihat dari deviasi standar kelompok perlakuan lebih kecil dari 20\% (15,81\%) sedangkan kelompok kendali memiliki deviasi standar yang lebih lebar $(24,89 \%)$, yang mengindikasikan adanya nilai AWPM yang memiliki distribusi yang cenderung kurang homogen.

Seperti tahap sebelumnya, perbedaan nilai rata-rata tidak bisa dijadikan referensi untuk melihat apakah kedua kelompok memang berbeda secara signifikan atau tidak. Untuk itu, peneliti akan menguji dengan uji Levene dan uji t. Berikut ini adalah hasilnya. Tahap pertama dengan menggunakan uji Levene memperlihatkan nilai probabilitas/Sig. adalah 0,138 dan terletak pada baris "Equal variances assumed". Karena 0,138>0,05 maka dapat disimpulkan bahwa varians dari kedua kelompok adalah identik atau sama. Untuk mempertegas hasil uji Levene, hasil uji t memperlihatkan nilai probabilitas atau "Sig. (2-tailed)" yang terletak pada baris "Equal variances assumed" adalah 0,284. Karena 0,284>0,05 maka dapat disimpulkan bahwa nilai rata-rata dari kedua kelompok yang diuji pada dasarnya tidak berbeda secara signifikan atau pada dasarnya adalah identik atau sama.

Berdasarkan dua fakta empiris tersebut, maka peneliti bisa memastikan bahwa kedua kelompok memang memiliki kinerja AWPM yang sama atau identik secara statistik. Artinya, kelompok kendali bisa menjadi instrumen untuk melihat apakah perlakuan yang akan diberikan memang memberi pengaruh yang signifikan atau sebaliknya.

\section{Perbandingan Kecepatan dan Ketepatan (AWPM) Pengetikan Kelompok Perlakuan dan Kelompok Kendali}


Sebanyak lima musik daerah yang digunakan untuk mengiringi kegiatan pengetikan kelompok perlakuan, yaitu musik daerah jawa gemelan (gending), Mangari Degung (Sunda), Cublekcublek Suweng (Jawa), Kebyar Bali (Bali), dan Oleg Tambulilingan (Bali).

Percobaan pertama dilakukan dengan mengukur AWPM dari kelompok yang mendapat perlakuan berupa tes kecepatan mengetik dengan mendengarkan musik Gamelan Jawa (Gending), sedangkan kelompok kendali melakukan tes kecepatan mengetik tanpa mendengarkan musik. Hasilnya, kelompok yang mendapatkan perlakuan memiliki rata-rata AWPM sebesar 50, sedangkan kelompok kendali sebesar 49,032. Deviasi standar, kedua kelompok memiliki distribusi data yang relatif dapat diterima, yaitu lebih rendah dari seperlima dari nilai rata-rata. Hasil uji beda yang dilakukan dalam dua tahap, yaitu: uji Levene dan uji t memperlihatkan perlakuan berupa musik Gamelan Jawa ternyata tidak menghasilkan perbedaan perolehan AWPM yang berbeda secara signifikan. Hal tersebut terlihat dari nilai Sig. (2-tailed) dari uji t yang memiliki nilai 0,625 (atau > $0,05)$ apabila diprediksi dengan menggunakan asumsi varians yang sama. Berdasarkan kajian empiris tersebut, maka dapat disimpulkan bahwa jenis musik Gamelan Jawa (Gending) tidak secara signifikan mempengaruhi kecepatan mengetik mahasiswa.

Selanjutnya, perbandingan antara kelompok kendali dengan responden yang mengetik sambil mendengarkan musik jenis Mangari Degung. Rata-rata AWPM kelompok perlakuan sebesar 50,938, sedangkan kelompok kendali memiliki rata-rata AWPM sebesar 51,452. Deviasi standar kedua kelompok lebih kecil dari 20\%. Untuk menguji apakah perbedaan perlakuan tersebut memberikan hasil rata-rata AWPM yang berbeda secara signifikan, maka dilakukan uji beda, dan hasilnya niali probabilitas/signifikansi sebesar 0,931 dan 0,807 (atau > 0,05). Hasil uji beda tersebut mengindikasikan bahwa rata-rata AWPM dari kelompok kendali dan kelompok yang mendengarkan musik Mangari Degung tidak berbeda secara signifikan.

Jenis musik ketiga yang diberikan kepada responden adalah musik Cublak-cublak Suweng. Hasilnya, responden yang mengetik dengan mendengarkan musik daerah Jawa Tengah Cublakcublak Suweng ternyata memiliki kinerja AWPM lebih baik daripada kelompok kendali, yaitu 54,500 berbanding 50,258. Dilihat dari deviasi standar, kedua kelompok tersebut memiliki nilai yang masih dapat ditoleransi $(<20 \%)$.Untuk membuktikan apakah musik Cublak-cublak Suweng memiliki pengaruh yang signifikan dalam meningkatkan nilai rata-rata AWPM, maka pertama dilakukan uji beda. Hasilnya, memiliki varian yang sama $(0,779>0,05)$ dan memiliki perbedaan yang signifikan $(0,006<0,05)$. Artinya musik daerah Cublak-cublak Suweng merupakan stimulus faktor lingkungan yang bersifat favorable terhadap responden sehingga kinerja AWPM mereka meningkat secara signifikan.

Eksplorasi selanjutnya dilakukan dengan menggunakan musik Kebyar Bali. Hasilnya, ratarata AWPM kelompok kendali $(40,548)$ ternyata memiliki nilai yang jauh lebih rendah daripada ratarata AWPM kelompok yang mengetik sambil mendengarkan musik Kebyar Bali $(52,641)$. Merujuk pada deviasi standar, rata-rata AWPM kelompok kendali $(22,83 \%)$ cenderung lebih tinggi dari norma, artinya nilai AWPM kelompok ini cenderung bersifat heterogen, memiliki kontinum distribusi AWPM yang lebih panjang. Sedangkan deviasi standar kelompok perlakuan di bawah $20 \%(15,64 \%)$. Hasil uji Levene menyatakan bahwa menyatakan bahwa varians dari kelompok yang mendengarkan musik Kebyar Bali dengan kelompok Kendali bersifat identik ( 0,871 atau >0,05). Dan hasil uji t mengindikasikan nilai probabilitas sebesar 0,000 atau $<0,05$. Artinya, nilai rata-rata AWPM antara kelompok kendali dengan kelompok yang mendengarkan musik Kebyar Bali memang berbeda secara signifikan.

Musik Oleg Tambulilingan merupakan perlakuan selanjutnya untuk responden, dalam rangka mengeksplorasi apakah jenis musik daerah ini mampu menstimulus responden untuk meningkatkan kinerja AWPM-nya. Hasilnya, rata-rata AWPM kelompok perlakuan memiliki nilai rata-rata AWPM yang lebih tinggi $(53,984)$ dari kelompok kendali $(43,258)$. Selanjutnya, merujuk pada deviasi standar dari kedua kelompok tersebut, dapat disimpulkan bahwa deviasi standar untuk kelompok kendali sedikit lebih tinggi dari norma (24,90\%). Artinya, nilai AWPM dari kelompok kendali bersifat menyebar, kurang homogen dibandingkan dengan kelompok yang mendengarkan 
musik Oleg Tambulilingan (13,93\%). Berdasarkan hasil uji beda, kelompok perlakuan dan kendali bersifat identik $(0,198)$ dan rata-rata AWPM dari kedua kelompok tersebut memiliki perbedaan yang signifikan $(0,000)$. Dengan perkataan lain, musik Oleg Tambulilingan merupakan jenis musik daerah yang bisa memberikan stimulus yang favorable sehingga responden mampu meningkatkan AWPMnya secara siginifikan.

Selanjutnya, untuk menguji apakah rata-rata nilai AWPM dari semua sampel berbeda secara signifikan atau tidak, peneliti menggunakan uji Anova. Hasilnya, semua sampel yang berjumlah enam buah pada dasarnya terlihat memiliki nilat rata-rata AWPM yang berbeda dan memiliki deviasi standar yang masih dapat diterima. Untuk menguji apakah nilai tersebut memang berbeda secara signifikan, maka diuji homogenitas varians, hasilnya menunjukkan angka 0,707 atau > 0,50 yang artinya enam sampel yang digunakan dalam penelitian ini memiliki varians yang sama. Karena asumsi Anova terpenuhi, maka selanjutnya diuji ANOVA, dan hasilnya nilai probabilitas output SPSS menunjukkan nilai 0,010 (lebih rendah dari 0,05). Artinya, nilai rata-rata AWPM dari enam sampel tersebut memang berbeda secara signifikan.

Setelah diketahui adanya perbedaan dari enam sampel tersebut, maka perlu diidentifikasi sampel mana yang bebeda dengan menggunakan analisis Bonferroni dan Tukey. Hasil analisis Bonferoni, perbedaan dari nilai rata-rata AWPM dari enam sampel terlihat signifikan pada sampel Cublak-cublak Suweng dengan sampel Kendali, dengan perbedaan sebesar 5,4677 dan sebaliknya antara sampel kendali dengan sampel Cublak-cublak Suweng, sebesar -5,4677.

Dengan demikian, walaupun Kebyar Bali dan Oleg Tambulilingan juga secara signifikan mempengaruhi nilai rata-rata AWPM, akan tetapi Cublak-cublak Suweng merupakan pembeda yang paling signifikan. Artinya, instrumen Cublak-cublak Suweng merupakan instrumen musik daerah yang paling mendapat prioritas untuk digunakan sebagai musik pengiring yang diharapkan bisa mempengaruhi kinerja pengetikan. Dan hasil tes Tukey

menunjukkan kelompok Kendali dan kelompok Cublak-cublak Suweng merupakan subset yang berbeda. Sampel sisanya merupakan anggota dari dua subset, dengan demikian maka instrumen Gamelan Jawa, Kebyar Bali, Mangari Degung, serta Oleg Tambulilingan pada dasarnya tidak cukup kuat untuk menjadi stimulus yang signifikan dalam mempengaruhi nilai rata-rata pencapaian AWPM responden.

Hasil ini mempertegas bahwa Cublak-cublak Suweng merupakan instrumen musik daerah yang paling baik dalam menstimulus responden untuk menghasilkan AWPM yang lebih tinggi. Secara visual, Cublak-cublak Suweng memang memberikan pengaruh yang paling besar dan terbukti secara statistik bersifat signifikan.

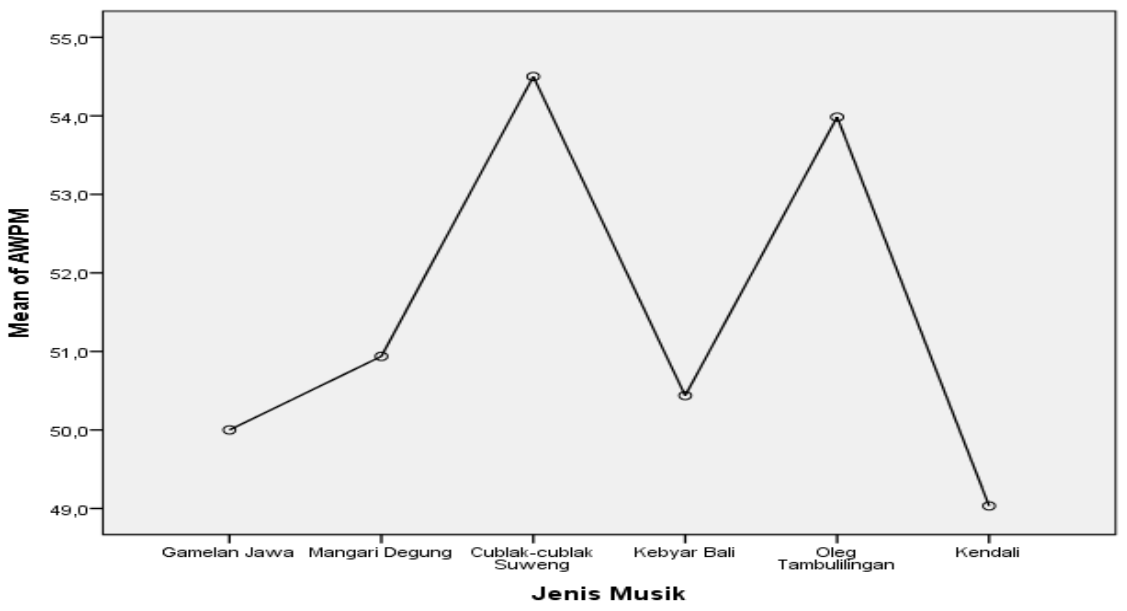

Gambar 4.1.Grafik AWPM Musik Daerah

Sumber: hasil pengolahan data, 2015 


\section{Kecepatan dan Ketepatan (AWPM) Pengetikan Akhir}

Untuk memperkuat adanya pengaruh musik daerah terhadap kemampuan mengetik para mahasiswa, sebuah kelompok diberi enam buah perlakuan, yaitu: mengetik tanpa musik dan mengetik dengan diiringi lima jenis musik daerah. Ketika mengetik dengan musik, jenis musik yang digunakan adalah: Gamelan Jawa (Cublak-cublak Suweng), Gamelan Jawa (Gending), Gamelan Sunda (Mangari degung), Gamelan Bali (Kebyar Bali, dan Oleng Tambulilingan). Hasilnya, rata-rata AWPM, terlihat pengetikan tanpa menggunakan musik (sebesar 40,938) memiliki rata-rata yang lebih rendah dibandingkan dengan pengetikan dengan menggunakan musik daerah (antara 50,750 sd. 52,594). Deviasi standar dari semua kinerja pengetikan berada dalam kisaran yang masih dapat diterima, yaitu: lebih rendah dari 20\%*rata-rata (Santoso, 2000). Artinya, data yang diperoleh dalam eksperimen ini cenderung bersifat homogen. Untuk melakukan uji beda dari enam sampel tersebut, salah satu asumsi yang harus dipenuhi adalah: semua sampel tersebut harus mempunyai varians yang sama. Oleh karena itu, diperlukan tes kehomogenan dari varians. Hasilnya, nilai probabilitas dari Levene tes adalah 0,753; lebih besar dari 0,05. Artinya, enam sampel yang digunakan dalam penelitian ini memiliki varians yang sama. Karena asumsi varians yang sama sudah terpenuhi, maka uji beda dengan menggunakan Anova dapat dilakukan. Hasilnya, nilai probabilitas sebesar 0,000, artinya rata-rata AWPM dari enam sampel memang berbeda secara signifikan. Dengan perkataan lain, penelitian ini berhasil membuktikan bahwa musik daerah memiliki pengaruh yang signifikan terhadap terhadap kinerja AWPM mahasiswa.

Untuk lebih memahami musik daerah apa yang benar-benar berbeda, yang bisa menghasilkan peningkatan kinerja AWPM secara signifikan, dapat dilihat dari hasil tes Tukey HSD dan Bonferroni. Hasil tes Tukey HSD memperlihatkan perbedaan rata-rata (lihat kolom "Mean Difference (I-J)") AWPM ketika mengetik dengan tidak menggunakan musik ternyata berbeda secara signifikan dengan mengetik dengan menggunakan musik daerah Gamelan Jawa (Cublak-cublak Suweng), Gamelan Jawa (Gending), Mangari degung, Kebyar Bali, dan Oleng Tambulilingan. Terlihat semua angka di kolom tersebut memiliki tanda * (bintang).

Ketika anggota sampel mengetik dengan menggunakan musik daerah Cublak-cublak Suweng, maka nilai rata-rata AWPM berbeda secara signifikan dengan nilai rata-rata ketika sampel mengetik tanpa musik. Sebaliknya, nilai rata-rata AWPM -nya tidak berbeda secara signifikan dengan nilai rata-rata AWPM ketika sampel mengetik dengan dilatarbelakangi musik Gamelan Jawa (Gending), Mangari degung, Kebyar Bali, dan Oleng Tambulilingan.

Hal yang sama terjadi untuk jenis musik lainnya, semuanya memiliki perbedaan rata-rata AWPM yang berbeda secara signifikan dengan nilai rata-rata AWPM ketika sampel mengetik tanpa diiringi musik; dan tidak memiliki perbedaan yang signifikan apabila dibandingkan dengan nilai ratarata AWPM ketika sampel diiringi oleh jenis musik daerah yang lain. Hasil tes Bonferroni juga bersifat identik dengan hasil tes Tukey HSD. Artinya, penelitian ini berhasil mengidentifikasi bahwa genre musik daerah memang secara signifikan bisa mempengaruhi nilai rata-rata AWPM.

Berbeda dengan uji sebelumnya, tes homogeneous subsets justru berusaha mengidentifikasi kelompok/grup/subset mana saja yang mempunyai perbedaan rata-rata AWPM yang tidak berbeda secara signifikan. Terlihat rata-rata AWPM mengetik tanpa diiringi musik berada dalam kelompok tersendiri, sedangkan hasil rata-rata AWPM pengetikan dengan menggunakan genre musik daerah berada pada kelompok yang lain. Artinya, hasil rata-rata AWPM pengetikan dengan diiringi genre musik daerah memang berbeda secara signifikan dengan rata-rata AWPM pengetikan tanpa diiringi musik.

Dengan demikian, maka hasil tes homogeneous subsets merupakan pelengkap dari hasil tes Bonferroni dan Tukey. Hasil dari tiga tes tersebut menunjukkan bahwa kemampuan mengetik (yang ditunjukkan oleh nilai rata-rata AWPM) akan meningkat secara signifikan apabila digunakan genre musik daerah sebagai latar belakangnya. Jadi, genre musik daerah bisa menjadi stimulan untuk meningkatkan kinerja rata-rata AWPM. 
Artinya, pada tahap ini peneliti bisa memberi bukti yang signifikan bahwa individu yang mengetik dengan diiringi oleh musik akan memiliki AWPM yang lebih baik dibandingkan dengan mengetik tanpa diiringi musik.

\section{Hasil Analisis Angket}

Untuk memperkuat hasil penelitian, di akhir eksperimen peneliti mendistribusikan angket untuk meyakinkan bahwa faktor musik memang dapat memberi stimulan yang bersifat positip untuk meningkatkan kinerja pengetikan mahasiswa. Kajian ini berfungsi untuk mengetahui apakah faktor internal dan eksternal yang ada dipersepsikan sama atau berbeda oleh kelompok perlakuan dan kelompok kendali. memiliki rata-rata yang berbeda atau sama.

Selain itu, peneliti menghitung lagi rata-rata AWPM dari kelompok perlakuan dan kelompok kendali. Hal ini berguna untuk memberi penegasan bahwa genre musik memiliki pengaruh terhadap kinerja AWPM mahasiswa. Berdasarkan nilai rata-rata faktor internal, eksternal, dan kinerja AWPM, kelompok perlakuan dan kendali memiliki nilai yang berbeda. Dilihat dari deviasi standar, semua nilai rata-rata memiliki deviasi standar yang masih dapat ditoleransi (di bawah 20\% ). Untuk menguji apakah nilai rata-rata tersebut apakah sama atau berbeda secara signifikan, peneliti menggunakan uji beda. Hasil tes Levene semua nilai $>0,05$ yang artinya kedua varians adalah sama atau identik, dan hasil uji t nilai probabilitas faktor eksternal 0,259 (atau >0,05) dan internal 0,259 (atau > 0,05) yang artinya kelompok perlakuan maupun kelompok kendali memiliki persepsi yang sama terhadap faktor-faktor internal maupun eksternal. Jadi, faktor internal dan eksternal tidak memiliki pengaruh terhadap kinerja AWPM, sebab keduanya memiliki nilai rata-rata yang sama.

Akan tetapi, untuk nilai rata-rata AWPM, varians kelompok perlakuan dan kelompok kendali tidak sama. Berdasarkan hasil tes Levene tersebut, maka nilai probabilitas dari uji beda adalah 0,000 atau <0,05. Artinya, nilai rata-rata AWPM antara kelompok perlakuan dan kelompok kendali memang berbeda secara signifikan.

Dengan demikian, hasil tersebut semakin menguatkan kesimpulan bahwa genre musik daerah memang secara signifikan mampu mempengaruhi kinerja AWPM. Ketika individu bekerja dengan diiringi genre musik daerah, mereka bisa menerima musik tersebut sebagai stimulan yang bersifat positif sehingga kinerja keyboarding mereka semakin optimal.

\section{Pembahasan}

\section{Pengaruh Musik Daerah terhadap Peningkatan Kecepatan dan Ketepatan Mengetik Mahasiswa}

Pada test awal kecepatan dan ketepatan mengetik mahasiswa dari kelompok perlakuan dan kelompok kendali menunjukkan kompetensi pengetikan yang sama, sehingga penelitian ini dapat dilanjutkan.

Sebanyak lima gendre musik instrumental yang diperdengarkan kepada kelompok perlakuan, yaitu: Gamelan Jawa yang terdiri dari Gending dan Cublek-cublek Suweng, Gamelan Sunda berupa Mangari Degung, dan Gamelan Bali yang terdiri dari Kebyar Bali dan Oleng Tambulilingan.

Berdasarkan kajian empiris tersebut, ternyata gendre Gamelan Jawa (Gending) tidak secara signifikan mempengaruhi kecepatan mengetik mahasiswa. Hal ini mungkin terjadi karena responden didominasi oleh suku Sunda sehingga mereka merasa tidak terlalu "familiar" dengan jenis musik ini. Selain itu, tempo musik Gamelan Jawa (Gending) yang digunakan dalam penelitian ini tergolong dalam tempo yang lambat sehingga responden mungkin merasa "kurang semangat" sehingga "alertness" atau kesiagaan dalam mengetik menjadi agar berkurang. Untuk itu, penelitian yang akan datang sebaiknya membagi musik Gamelan Jawa menjadi beberapa jenis, mulai dari yang bertempo lambat sampai dengan yang bertempo cepat.

Musik merupakan salah satu bentuk faktor lingkungan fisik yang dapat mempengaruhi kemampuan individu dalam mengadopsi keyboarding skill. Perspektif ilmu psikologi lingkungan menyatakan bahwa lingkungan fisik yang ada disekitar individu membuat dia menjadi merasa nyaman atau sebaliknya (Raharso \& Raharso, 2006). Kenyamanan atau ketidaknyamanan tersebut selanjutnya akan mempengaruhi semangat kerja individu dalam mempelajari teknik-teknik keyboarding skill. Kondisi tersebut bisa dijelaskan oleh Model Stimulus-Response dari Mehrabian- 
Russel (Richardson et al., 1996). Kajian dalam ilmu manajemen kantor juga menyatakan hal yang sama, yaitu: musik bisa mempengaruhi kinerja seorang individu (Suryani \& Raharso, 2005).

Dengan demikian, musik Gamelan Jawa (Gending) merupakan stimulus yang diperoleh oleh individu yang sedang belajar keyboarding skill. Setelah mendapat stimulus tersebut, individu akan terpengaruh mood atau emosinya. Pengaruh tersebut selanjutnya akan muncul dalam bentuk respon berupa penerimaan (approach) atau penolakan (avoidance) terhadap stimulus musik tersebut. Karena hasil tes kecepatan tidak menunjukkan hasil peningkatan atau penurunan kecepatan yang signifikan, maka musik Gamelan Jawa merupakan stimulus yang bersifat netral, tidak memberi pengaruh yang signifikan terhadap kemampuan mengetik, dalam hal ini kinerja AWPM-nya.

Pengujian yang kedua dengan memperdengarkan gendre musik Mangari Degung, ternyata kelompok kendali memiliki rata-rata AWPM yang lebih tinggi sedikit dari kelompok perlakuan, namun perbedaan tersebut tidak signifikan. Oleh karena itu, dapat dibuat kesimpulan bahwa jenis musik Mangari Degung tidak mampu memberikan atmosfir yang favorable sehingga kinerja pengetikan para responden tidak meningkat secara signifikan. Musik Mangari Degung merupakan salah satu musik khas Parahyangan, dimana responden sebagian besar berasal dari daerah ini. Artinya, musik Mangari Degung pada dasarnya dikenali oleh sebagian besar responden (24 mahasiswa dari 32 responden). Dengan demikian, familiarity bukan menjadi faktor yang bisa memicu meningkatnya kinerja pengetikan.

Tidak adanya peningkatan AWPM secara signifikan mungkin terjadi karena jenis musik Mangari Degung yang digunakan merupakan musik yang bertempo lambat sehingga tidak memicu semangat para responden untuk mengetik secara intensif.

Untuk itu, di masa yang akan datang juga perlu diujicoba pengaruh musik Degung dengan membedakan tempo dari musik daerah tersebut.

Gendre musik yang ketiga diperdengarkan adalah Cublek-cublek Suweng yang berasal dari daerah Jawa, dan hasilnya mahasiswa dari kelompok perlakuan memiliki rata-rata AWPM yang lebih tinggi dari kelompok kendali secara signifikan. Dapat dikatakan, bahwa musik daerah Cublek-cublek Suweng merupakan stimulus faktor lingkungan yang bersifat favorable terhadap mahasiswa sehingga kinerja AWPM mereka meningkat secara signifikan.

Dengan demikian, jenis musik daerah ini merupakan salah satu alternatif dari sekian banyak musik daerah yang bisa menjadi instrumen untuk meningkatkan kinerja pengetikan para mahasiswa secara signifikan. Hal tersebut bisa terjadi karena musik Cublak-cublak Suweng memiliki tempo yang cepat dan riang sehingga "alertness" para mahasiswa menjadi semakin tinggi yang berimplikasi pada konsentrasi yang semakin baik. Lagu ini termasuk dalam tipe "tembang dolanan (lagu permainan)" yang ringan, mengalir sehingga menciptakan suasana riang. Hasil penelitian ini sejalan dengan penelitian Colona (2008) yang mengidentifikasi bahwa musik bergenre "fast rock" memiliki pengaruh yang lebih dominan terhadap kecepatan pengetikan seorang individu. Dalam perspektif tertentu, jenis musik Cublak-cublak Suweng memiliki tempo yang cepat, mirip dengan musik rock yang bertempo cepat.

Musik daerah keempat yang diperdengarkan adalah gamelan Bali yaitu Kebyar Bali, dan hasilnya mahasiswa kelompok perlakuan memiliki rata-rata AWPM yang lebih tinggi dibanding kelompok kendali secara signifikan.

Kebyar Bali merupakan musik dengan instrumen gong sebagai instrumen utama, yang secara serentak diikuti secara bersama-sama oleh hampir semua instrumen tungguhan pada perangkatnya kecuali tungguhan suling, kajar, rebab, kempul, bebende kemong, kajar dan terompong. Bunyi gong yang bertalu-talu merupakan elemen yang berfungsi sebagai "pembuat kaget" pendengarnya. Musik Kebyar Bali bersifat sangat dinamis dan keras sehingga mampu membangkitkan semangat. Stimulus musik tersebut dipersepsikan secara positif oleh responden sehingga mereka memiliki semangat untuk mengetik dengan intensif sehingga nilai rata-rata AWPM nya meningkat secara signifikan.

Musik daerah kelima yang diperdengarkan adalah gamelan Bali yaitu Oleg Tambulilingan. Hasilnya, rata-rata AWPM mahasiswa dari kelompok perlakuan jauh lebih tinggi dari pada kelompok kendali. Peroleh rata-rata AWPM dari dua kelompok terebut berbeda secara signifikan. Artinya, 
musik daerah Oleg Tambulilingan merupakan jenis musik yang memberikan stimulus yang favorable sehingga mahasiswa mampu meningkatkan AWPM-nya secara signifikan.

Musik Oleg Tambulilingan pada awalnya merupakan tarian yang mengadopsi perilaku kumbang yang sedang mengisap madu. Gerakan-gerakan lincah kumbang yang secara dinamis bergerak mengisap madu dan berpindah dari satu bunga ke bunga yang lain juga terekspresikan dalam musik pengiring dari tarian ini. Sifat musik pengiring tarian ini bersifat mengalir dan dinamis sehingga "fit" dengan kebutuhan para pengetik.

Dengan demikian, penelitian berhasil mengidentifikasi tiga musik daerah yang bisa menjadi stimulus yang favorable atau positif bagi responden yang melakukan pekerjaan dengan menggunakan keyboard, yaitu: Cublak-cublak Suweng, Kebyar Bali, dan Oleg Tambulilingan. Secara signifikan tiga jenis musik daerah tersebut mampu meningkatkan kinerja AWPM para mahasiswan. Oleh karena itu, tiga jenis musik daerah tersebut bisa menjadi alternatif untuk menggantikan musik barat yang biasanya digunakan sebagai pengiring atau latar belakang proses pengetikan.

Untuk memperkuat hasil penelitian, bahwa musik daerah dapat mempengaruhi peningkatan kecepatan dan ketepatan (AWPM) mahasiswa, maka mahasiswa dari kelompok perlakuan dites kembali dengan iringan lima musik daerah yang sama dengan sebelumnya dan tanpa diiringi musik daerah. Hasilnya, rata-rata AWPM tanpa menggunakan musik daerah lebih rendah dibandingkan dengan rata-rata AWPM yang diiringi lima musik daerah tersebut. Berdasarkan hasil uji Anova, ratarata AWPM dari enam sampel tersebut memiliki perbedaan yang signifikan. Dengan perkataan lain, maka penelitian ini berhasil membuktikan bahwa musik daerah memiliki pengaruh yang signifikan terhadap peningkatan kecepatan dan ketepatan mengetik mahasiswa.

Di samping itu, peneliti juga menyebarkan angket yang bertujuan untuk meyakinkan bahwa peningkatan kecepatan dan ketepatan mengetik mahasiswa itu benar-benar dipengaruhi oleh musik daerah, bukan oleh faktor internal dan eksternal.

Hasil dari angket tersebut, menyatakan bahwa kelompok yang bekerja dengan diiringi musik daerah maupun kelompok yang bekerja tanpa musik daerah memiliki persepsi yang sama terhadap faktor-faktor internal maupun eksternal. Jadi, faktor internal dan eksternal tidak memiliki pengaruh terhadap kinerja AWPM mahasiswa

Dengan demikian, hasil tersebut semakin menguatkan kesimpulan bahwa genre musik daerah memang secara signifikan mampu mempengaruhi kinerja AWPM. Ketika individu bekerja dengan diiringi genre musik daerah, mereka dapat menerima musik tersebut sebagai stimulan yang bersifat positif sehingga kinerja keyboarding mereka semakin optimal.

Konsekuensi, sistem pembelajaran keyboarding skill perlu mendayagunakan berbagai genre musik, agar mahasiswa memiliki kemampuan keyboarding skill yang lebih baik. Dalam hal ini, genre musik daerah juga bisa didayagunakan karena terbukti secara signifikan memberi pengaruh terhadap kinerja keyboarding skill.

Selain itu, pengelola laboratorium (yang berfungsi sebagai tempat pembelajaran keyboarding skill) perlu memfasilitasi berbagai genre musik di laboratorium tersebut. Hal tersebut dapat dilakukan dengan menyediakan berbagai genre musik yang tersedia pada setiap PC yang digunakan oleh mahasiswa, maupun menyediakan peralatan "sound system" sehingga mahasiswa bisa mendengarkan musik secara publik, tidak secara personal.

\section{Genre Musik Daerah yang Mempengaruhi Peningkatan Kecepatan dan Ketepatan Mengetik Mahasiswa}

Penelitian ini telah membuktikan bahwa musik daerah dapat mempengaruhi peningkatan kecepatan dan ketepatan mengetik mahasiswa secara signifikan.

Sebanyak lima musik daerah yang telah digunakan untuk mengiringi kegiatan pengetikan, yaitu gamelan Jawa yang terdiri dari Gending dan Cublek-cublek Suweng, gamelan Sunda yaitu Mangari Degung, dan gamelan Bali yaitu Kebyar Bali dan Oleg Tambulilingan. Hasilnya, musik daerah gamelan Jawa (Gending) memberikan stimulus yang bersifat netral, artinya tidak memberi pengaruh yang signifikan terhadap kecepatan dan ketepatan mengetik mahasiswa. Begitu juga, musik daerah gamelan Sunda (Mangari Degung) tidak mampu memberikan atmosfir yang favorable yang dapat meningkatkan 
kecepatan dan ketepatan mengetik mahasiswa. Kedua jenis musik daerah ini sama-sama memiliki tempo musik yang lambat sehingga kurang memberikan semangat bagi mahasiswa untuk mengetik secara intensif. Sedangkan jenis musik daerah yang lainnya, yaitu Cublek-cublek Suweng, Kebyar Bali, dan Oleg Tambulilingan merupakan musik daerah yang mampu memberikan pengaruh yang signifikan terhadap peningkatan kecepatan dan ketepatan mengetik. Ketiga musik daerah yang mempengaruhi secara signifikan terhadap peningkatan kecepatan dan ketepatan mengetik tersebut sama-sama memiliki tempo musik yang cepat. Jenis musik yang bertempo cepat ini memberikan semangat kepada mahasiswa sehingga memberikan respon yang positip terhadap kompetensi mengetik mahasiswa. Hal ini sejalan dengan hasil penelitian Colona (2008) yang mengidentifikasikan bahwa musik bergendre "fast rock" memiliki pengaruh yang lebih dominan terhadap kecepatan pengetikan seorang individu. Namun, dari ketiga gendre musik daerah tersebut di atas, Cublek-cublek Suweng merupakan musik daerah yang paling dominan dalam meningkatkan kecepatan dan ketepatan mengetik mahasiswa. Cublek-cublek Suweng merupakan instrumen musik daerah yang paling baik dalam menstimulus mahasiswa untuk menghasilkan AWPM yang lebih tinggi. Secara visual, Cublek-cublek Suweng memang memberikan pengaruh yang paling besar dan terbukti secara statistik bersifat signifikan.

Dalam melaksanakan penelitian ini, terdapat kendala tentang ketersediaan CD musik daerah tersebut. Musik yang digunakan untuk mengiringi kegiatan pengetikan tersebut berupa musik instrumental daerah yang benar-benar menggunakan alat musik daerah. Misalnya musik instrumental degung, maka alat musik yang digunakan adalah saron, demung, gong, jenglong, kendang, dan suling. Namun ternyata, musik instrumental daerah tersebut sulit dicari. Beberapa toko CD dari mulai yang ada di mall maupun yang di pinggir jalan sudah didatangi, namun hanya sedikit yang dapat ditemukan. Untuk mengatasi hambatan tesebut, peneliti sudah mencoba browsing di internet, namun hasilnyapun kurang memuaskan. Oleh sebab itu, pada penelitian ini musik intrumental daerah yang telah didengarkan kepada mahasiswa untuk mengiringi kegiatan pengetikan adalah musik daerah Sunda, Jawa, dan Bali.

\section{KESIMPULAN DAN SARAN \\ Kesimpulan}

Berdasarkan hasil eksperimen dan diperkuat dari hasil angket yang didistribusikan kepada mahasiswa, penelitian ini berhasil menjawab dua tujuan utama dari penelitian ini, yaitu sebagai berikut.

a. Penelitian berhasil membuktikan bahwa musik daerah dapat mempengaruhi secara signifikan terhadap peningkatan kecepatan dan ketepatan mengetik mahasiswa. Kehadiran musik daerah ini dapat meningkatkan rata-rata kecepatan dan ketepatan (AWPM) mengetik mahasiswa secara signifikan.

b. Penelitian juga berhasil mengidentikasi bahwa genre musik daerah Cublek-cublek Suweng, Kebyar Bali dan Oleg Tambulilingan mampu meningkatkan secara signifikan kecepatan dan ketepatan mengetik mahasiswa. Namun, Cublek-cublek Suweng merupakan musik daerah yang memiliki pengaruh terbaik dalam meningkatkan rata-rata kecepatan dan ketepatan (AWPM) mengetik mahasiswa.

\section{Saran}

a. Alunan musik daerah terbukti dapat memberikan stimulus yang positif terhadap peningkatan kecepatan dan ketepatan (AWPM) mahasiswa, maka sebaiknya proses pembelajaran mata kuliah Keyboarding Skill perlu dilengkapi dengan berbagai macam musik instrumental daerah dari Sabang sampai Merauke, terutama musik daerah yang memiliki tempo yang cepat dan ceria/riang.

b. Sebaiknya dilakukan penelitian lanjutan tentang pengaruh musik daerah yang lain terhadap peningakatan keybording skill mahasiswa, misalnya musik dari Kalimantan dan Sulawesi.

\section{DAFTAR PUSTAKA}

Adomi, Esharenana E. \& Anie, Silvester O. 2006. An Assesment of Computer Literacy Skills of Profesionals in Nigerian University Libraries. Library Hi Tech News, No. 2, pp. 10-14.

Alaska Departement of Education. 1991. Teaching Keyboarding. Retrieved, June 27, 2012, from Ebscohost database.

Astuti, Dwi. \& Suhardi, Bambang. 2006. Jurnal Seminar Nasional Ergonomi , 21-22 November. UNS Solo. 
Bartholome, L. 2002. Typewriting/keyboarding Instruction in Elementary Schools. Diambil dari http://www.usoe.k12.ut.us/ate/keyboarding/Articles/Bartholome.htm; tanggal 27 Mei 2013.

Business Education Center. 2005. Keyboarding Methodology Instructional Guide for Teachers and Administrators. Virginia: Office of Career and Technical Education Services, Departement of Education.

Colona, Joseph E. 2008. How Does Music Affect Typing Speed? California State Science Fair: Project No. J0304.

Cooper, W. 1983. Cognitive Aspects of Skilled Typewriting. New York: Springer-Verlag.

Hallam, Susan; Price, John; \& Katsarou, Georgia. 2002. The Effects of Background Music on Primary School Pupils' Task Perfmance. Educational Studies, Vol. 28, No. 2, pp. 111-122.

Jensen, Milton B. 1931. The Influence of Jazz and Dirge Music Upon Speed and Accuracy of Typing. Journal of Educational Psychology, Vol. 22, No. 6, September, pp. 458-462.

Learning Company Properties, Inc. 1999. Mavis Beacon Teaches Typing User's Guide. California: Broderbund.

MacLean, G. 1994. Teaching Keyboarding. Little Rock, Arkansas: Delta Pi Epsilon.

McCraty, Rollin; Atkinson, Mike; Rein, Glen; \& Watkins, Alan D. 1996. Music Enhances The Effect of Positive Emotional States on Slivari IgA. Stress Medicine, Vol. 12, pp. 167-175.

Michael Page International Inc., Specialists in Office Support Recruitment, diunduh tanggal 26 Mei 2015 dari: : http://www.michaelpage.com/our-expertise/page-personnel-office-support/what$\underline{\text { makes-a-good-administrative-assistant }}$

National Business Education Association. 1992. Elementary/Middle School Keyboarding Strategies Guide. Reston, VA: National Business Education Association.

Nieman, P. 1996. Introducing Early Keyboarding Skills. Business Education Forum, Vol. 51, No. 1, pp. 27-30, October.

Philips, Sydelle \& Radford, Teresa, 1984, 50 Typing test: series 1 Australian standard, Melbourne: Pitma

Porter, De, Hernacki, 2000. Quantum Learning: Unleasing The Genius In You, penerjemah Alwiyah Abdurrahman Kaifa, Bandung, Cetakan VII.

Raharso, Mohamad \& Raharso, Sri. 2006. Peran Servicescapes di Wisata Leisure. Jurnal Ekonomi dan Manajemen, Vol. 7, No. 2, Juni, hal. 181-185.

Raharso, Sri \& Nurswastuti, M.M. 2003. Meningkatkan Keyboarding Skills: antara mesin ketik manual vs komputer, serta antara manuskrip Bahasa Inggris vs Bahasa Indonesia. Jurnal Tata Niaga, Volume III, No. 3, Desember 2003, hal 50-60.

Raharso, Sri \& Nurswastuti, M.M. 2004. Meningkatkan Kecepatan dan Akurasi Pengetikan dengan Mengadopsi Software Keyboarding Skills, Proceeding of the Research and Studies - Teaching Grant I, Technological and Professional Skills Development Sector Project (ADB Loan No. 1792INO), Direktorat Jendral Pendidikan Tinggi - Departemen Pendidikan Nasional, Desember, hal.152-167.

Richardson, P.; Jain, A.K.; \& Dick, A. 1996. The Influence of Store Aesthetics on Evaluation of Private Label Brands. Journal of Product \& Brand Management, Vol. 5, No. 1, pp. 19-28.

Robinson, Hoggat; Shank, Crawford; \& Beaumont, Erickson. 1999. Middle School Keyboarding for Computer Success. 1st Edition. Cincinnati, OH: Profesional and Educational.

Salim, Danny, 2010. Pengaruh Musik terhadap Konsentrasi Belajar Siswa Kelas 2 SMUK 1 Salatiga. Jurnal Musik. Vol 2, No. 1, Agustus, hal 23 - 32.

Santoso, Singgih. 2000. Buku Latihan SPSS Statistik Parametrik. Jakarta: Elex Media Komputindo.

Schmidt, B. 1985. Keyboarding: Classroom Problems and Solutions. Delta Pi Epsilon Tips, Vol. 1, No. 1.

Setiawardani, Maya, dkk. 2013. Mengembangkan Keyboarding Skills Berbasis Permintaan Industri Melalui Software Pengetikan Bermanuskrip Bahasa Indonesia. Politeknik Negeri Bandung

Skifstad, Lisa. 2003. A Study to Determine The Necessity of Re-Teaching Keyboarding at The 6th Grade Level. Unpublished Master Tesis, University of Wisconsin.

Soejoeti, Kurnianto, Norman. 2005. Pengaruh Musik Pengiring Kerja terhadap Motivasi Kerja, Kepuasan Kerja dan Produktivitas Kerja Karyawan Stasiun Karantina Hewan dan Tumbuhan Tanjung emas Semarang, Thesis. UGM Yogyakarta 
Suryani, Sri \& Raharso, Sri. 2005. Peran Lingkungan Fisik Kantor dalam Mencegah Hilangnya Gairah Kerja (Burnout). Jurnal Tata Niaga, Vol. 5, No. 1, Juni, hal. 108-115.

Tjahyawati \& Raharso. 2013. Memberdayakan Musik dalam Rangka Meningkatkan Keyboarding skill Mahasiswa, Politeknik Negeri Bandung.

Wentling, R. M. 1992. Business Professional and Keyboarding Skills. Business Education Forum, Vol 46, No. 3, pp. 30-32.

Wetzel, K. 1985. Keyboarding Skills: Elementary, My Dear Teacher. The Computing Teacher, September, p. 15-19.

Wikipedia 2015. Word per minute. diunduh tanggal 25 Mei 2015, dari: http://en.wikipedia.org/wiki/word_per_minute.

Wiseman, G. 2000. Keys at Their Fingertips: A study supporting development of a resource package for the teaching of touch-keyboarding skills in Upper Elementary Classrooms Equipped with Portable Keyboards. Diunduh tanggal 01 Mei 2013, dari: http://gwiseman.home.mindspring.com/keys/TeachTouch_GW2000.pdf.

Zeitz, L. (2005). Keyboarding made simple: Learn the best techniques for keyboarding like a pro. New York: Broadway Books. 